\title{
Nárek - izgubljen slovenski folklorni žanr
}

\author{
MariJa Stanonik \\ Inštitut za slovensko narodopisje ZRC SAZU, Novi trg 5, SI - 1000 Ljubljana, \\ stanonik@zrc-sazu.si
}

SCN III/1 [2010], 174-209

\begin{abstract}
Narek in narekanje sta se začela opuščati sredi 19. stoletja. Na srečo je dovolj dokumentirano v zapisih besedil in opisih šeg. Besedila razkrivajo izjemno poetično moč, ki črpa iz izkušenj in čustvovanja. Obredna besedila ohranjajo stare mitične poteze (Bela krajina), način izvajanja (Istra) in kažejo na usihanje izvirnih funkcij (Rezija) in so izreden dokument preteklega načina življenja (Prekmurje, Porabje). Sodobni življenjski stili in ideje so zakrile izvirni pomen in smisel žalovanja. Oropani svojega duhovnega pomena so se nekaj časa ohranjali kot družbeni korektiv (revne ženske so bile za narekanje plačane). Danes narekanje nadomeščajo pogrebni govori.
\end{abstract}

Laments and lamentation began to dwindle in the mid $19^{\text {th }}$ century. Fortunately, they have been documented in the form of recorded texts and descriptions of the custom. The texts reveal surprising poetic intensity, driven by powerful experiences and emotions. The preserved ritual texts with ancient mythological features (Bela krajina), with data on their performance (Istria), and with indications of the deterioration of their original function (Resia) are outstanding documents of a past lifestyle (Prekmurje - Porabje). Modern lifestyles and ideas obscured the original meaning and sense of lamentation. Robbed of its spiritual significance, lamentation was for some time preserved as a social corrective (poor women were paid for it). Nowadays, lamentation is replaced by funeral speeches.

Ključne besede: nárek, narekanje, žanr, stilemi, šega

Key words: genre, literary folklore, custom, corpse, lamentation

\section{Uvod}

Nárek, kar je ime žanra, in narekanje, narekovanje, naricanje kot ime za njegovo uporabo, sta se začela opuščati že sredi 19. stoletja. Na srečo so nekateri pohiteli in ga vsaj deloma dokumentirali z zapisom besedil in opisom šege. 


\section{Razne oblike slovesa od mrliča}

Pri slovesu mrliča od doma v grob so včasih obstajale številne šege, ki so se do danes močno osiromašile in prenovile. Članek se omejuje samo na tiste, ki so povezane $\mathrm{z}$ ubesedovanjem.

Nekdaj so povsod imeli mrliča doma na parah. Le najbolj zavrženi in zapuščeni so ležali v »mrtvašnici«, kot so dejali prostoru, kjer so hranili orodje za kopanje jam in oskrbovanje pokopališča. ${ }^{1}$

Včasih se je na Gorenjskem ${ }^{2}$ in Dolenjskem pogrebni sprevod proti pokopališču ustavil kje na meji domače vasi, najraje pri kakem vaškem znamenju, imenovanem»kerlejž«; po dogovoru se je eden izmed pogrebcev v mrličevem imenu poslovil od sorodnikov in znancev. Navadno je z močnim glasom zavpil nekako tako:

Če je kdo na rajnkega hud, naj mu oprosti (Orel 1944: 310).

V Slovenskih goricah so nekdaj rakev z mrličem položili na hišni prag ali pred vrata. Najstarejši med pogrebci se je vstopil k mrličevem zglavju in poslovil v njegovem imenu:

Srečno, draga moja deca! Vse mi odpustite, če sem vas kdaj razžalil. Tudi jaz vam odpuščam, kar je bilo nepravega med nami. Molite zame in bodite pridni, da se bomo nekoč videli nad zvezdami (Orel 1944: 310).

Ali se tak način poslavljanja v novi obliki vrača na naša pokopališča? ${ }^{3}$

Z začetka 20. stoletja je ohranjeno nad petdeset objavljenih pesmi z motiviko poslavljanja s tega sveta in smrti, in to $\mathrm{v}$ prvi osebi, kar se oblikovno navezuje na zgornje besedilo. To pomeni, da se je vloga slovesa rajnega začela seliti iz neposredne situacije pogreba v območje estetskega. Nastajale so pesmi - vložnice (Stanonik 1995: 218-226), v katerih nastopa že zagrobni lirski osebek oz. upovedena oseba. Take pesmi niso omejene le na eno pokrajino. Naslednje besedilo je iz Hudajužne v Baški grapi:

\footnotetext{
${ }^{1}$ Spomnimo se zadevnih motivov iz starejše slovenske literature.

${ }^{2}$ Mače pri Preddvoru vse dotlej, dokler niso zgradili mrliške vežice pred nekaj leti. Avtopsija.

${ }^{3}$ Vincenc Gotthardt, Poseben govor na pogrebu, Nedelja 79, 13. sept. 2009, 3: Neka žena iz Podjune je v svoji oporoki zapisala, naj na njenem pogrebu ne bo govora. Namesto tega naj se prebere besedilo, ki ga je priložila oporoki. V njem se je še zadnjič obrnila na farane, s katerimi se je srečevala nedeljo za nedeljo in tudi med tednom. Zapisala je nekaj iz svojega življenja, še bolj pa je v besedilu zbranim povedala nekaj besed v slovo. Ali se ne bi mogli učiti od te žene? [...] Starejši se radi pritožujejo, da otroci nimajo časa, da bi jih poslušali, ko jim pripovedujejo iz svojega življenja. Morda se z napisanim da kaj rešiti. »Kaj ko bi, čeprav je to na začetku težko, kar je najbolj pomembno, zapisovali. Če drugače ne, samo z nekaj besedami. Potomci bodo gotovo hvaležni, najbrž pa tudi žalostni, da si niso vzeli časa za poslušanje.«
} 
Smo na vertu rožce brali, Vedno smo se ž njimi igrali, Zdaj se pa ne bomo več,

Moja leta so že preč.

Snoč okol enajste ure

Slišal se je glas Gospoda,

Smrt na duri potrklja:

»Mlada Lenka, si doma?"

Vsi ljudje so m' pripovedovali,

Dohtarji so m' trošt dajali,

Trošt pa ne pomaga nič,

Moja leta so že preč.

Po spovednika so mi poslali,

Svečo so mi v roke dali,

Smert odloga nič ne da,

Hitro, hitro vse konča.

Mamka so strašno zavpili,

Ker so me serčno ljubili;

»O spreljuba moja hči,

Večna luč naj ti gori!!

Vsi purgarski in ti drugi,

Jest ležim v mertvaški trugi,

Jest vam podam merzlo roko,

Preden grem v črno zemljo (Štrekelj 1904-1907: 621).

Iz Prekmurja je ohranjen spomin na različico takega slovesa. Na dan pogreba pride učitelj, poje in v pesmi jemlje v imenu mrliča slovo od vseh sorodnikov, prijateljev in znancev ter imenuje vsakega po imenu (Trstenjak 1884: 341). Take poslovilne pesmi so bile še sredi 20. stoletja razširjene na Dolenjskem. Pri Sv. Juriju pod Kumom so med drugim takole govorili umrlemu oz. pogrebcem:

Dober večer vam voščim vsem!

Pa kaj je to, ki je zdaj mrtvo?

Da, vaša mamica umrli so.

Nocoj to noč sem še pri vas,

a jutri rajžam proč od vas.

Pa jemljem slovo prav žalostno

od svojih staršev prav lepo ... (Orel 1944: 310-311).

V večjem delu Štajerske so še v prvi polovici 20. stoletja zlagali tako imenovana slovesa (Kumer 1968: 111-118; Klobčar 2002), pesmi v spomin umrlemu, še posebno če ga je doletela nesreča. Prav zaradi netipičnih okoliščin smrti se te pesmi niso sfolklorizirale v celoti, temveč le posamezni deli, ki so dobili posrečeno ime »potujoči verzi« (Kumer 1965). 


\section{Obredno objokovanje umrlih}

Na drugi strani so se domači poslavljali in ločevali od mrtvega s posebnim glasnim tarnanjem ali jadikovanjem, žalovanjem, imenovanim nárek, narekanje, narekovanje, naricanje: »Te besede sklada vsaka žena po svoje, po hipnih vtisih, kakor ji narekuje razžaloščeno srce« (Rutar 1899), predvsem za možem in otrokom; z njimi izraža svojo žalost, slavi dobre lastnosti pokojnega in mu daje ljubkovalna imena. Po vsebini je narekovanje glasna, z jokom in stokom združena tožba za mrličem, objokovanje z izbranimi vznesenimi besedami; po obliki je nekakšno recitiranje, ki včasih preide v otožno pesem.

Narekanje je "pradavna ostalina indoevropskega mrtvaškega obredja «. ${ }^{4}$ Njegova naloga je s čim večjim hrupom odganjati zle sile, ki se želijo polastiti pokojnikove duše. Polagoma je tak pomen te šege zbledel in se prenesel na čustveno polje obsmrtnega dogajanja. Začel je zgubljati svojo vlogo, saj marsikdaj ni bilo pravega sorazmerja med čustvenim stališčem do pokojnega in silnostjo joka na pogrebu. Po prvotnem vzorcu je bilo jadikovanja toliko več, kolikor večja je bila nevarnost, da si pokojnika zle sile podvržejo; kar pomeni, da je bil za življenja za svojo okolico lahko zelo naporen in ni užival čustvene naklonjenosti. Po drugem vzorcu naj bi jokali le za ljubljeno osebo (Orel 1944: 310-311).

Narékali so domači, predvsem žene, ali nalašč za to najete jokávke, narékavice, naricalke. Narekuje predvsem žena za možem, hčerka za materjo ali bratom, ali več najetih žena skupaj. V tožbi ali narekanju sprašujejo mrtvega, zakaj da jih je tako nenadoma zapustil, opisujejo veliko žalost zaradi njegovega odhoda s tega sveta, nadevajo mu najlepša in najnežnejša imena, naštevajo njegove lepe lastnosti ter ga na dolgo in široko hvalijo. To se je dogajalo ob pogrebu pri hiši ali na pokopališču, ponekod pa tudi še po pogrebu več dni pred hišo.

Svoje dni je bila šega na Slovenskem splošna. Najdlje se je ohranila v obmejnih pokrajinah slovenskega etničnega ozemlja: v Reziji, Beneški Sloveniji, Trenti, Istri, Beli krajini in v Prekmurju. V Porabju je bila ponekod navada, da sta na pokopališču najeti ženski hvalili rajnega $\mathrm{z}$ narekanjem in se je nova vdova s petjem zahvalila na pokopališču pogrebcem. Posebnost Slovenskega Porabja je, da je tudi mož jokal za rajno ženo (Novak 1960: 190).

\section{Predstavitev gradiva}

Vsa predstavljena besedila so iz časopisnih objav sredi 19. stoletja. Tu so prvič kronološko zbrana na enem mestu, kar omogoča njihovo vsebinsko in stilno primerjavo. Če pokrajine njihovega pojavljanja (Prekmurje, Bela Krajina, Istra, Trenta, Beneška Slovenija, Rezija) med seboj povežemo, objemajo slovensko

\footnotetext{
${ }^{4}$ V bližnjem kulturnem okolju (Južni Slovani) se je praksa narekanja najdlje ohranila. Slovenski vojaki so imeli še priložnost sami doživeti ta obred (ustni vir, Žiri).
} 
etnično ozemlje v obliki podkve. Le Koroška na severu ostaja doslej brez kakršnih koli podatkov o narekanju.

\subsection{Bela krajina}

Najzgodnejše poročilo o narekanju je iz Bele krajine. Po ugotovitvi Karla Štreklja (1904-1907: 610) je o njem pisal že Janez J. Valvazor:5

Za žalovanje služi stara žena, ki mora objokovati smrt. Poje skoraj monotono, toda popolnoma žalostno in pripoveduje o vsem, kar je on v svojem življenju dobrega ali slavnega storil, in enako, kar bi v prihodnje še lepega mogel storiti. Sprašuje tudi naravnost, zakaj smrt: "Zakaj si umrl? Kaj se ti zdi? Zakaj le? Imel si vendar dobro, lepo, prijazno, zvesto itn. ženo. Dragi, povej mi vendar, zakaj si umrl? Kakšna nesreča I škoda, da si umrl!! In podobno norih vprašanj na tak razvlečen način je še več; vendar vse enako pojoče z žalostnim tonom. Čim sposobnejša je tako lamentirati in tarnati, tem pogosteje je k temu naročena. Posebno je to pri Vinici, kakor tudi nad Kolpo in njenim območjem enak način, ki se ujema z žalovanjem krščanskih narodov v Turčiji, posebno pa z grškim in ruskim: čeprav različne okoliščine pri tem drugače potekajo in se z iz dežele $v$ deželo spreminjajo. ${ }^{6}$

Zadnji del v navedenem odlomku nakazuje, da je Valvazor do narekanja zadržan in ga povezuje predvsem s pravoslavnimi kristjani. ${ }^{7} \mathrm{~V}$ slovenščini je po dosedanjem vedenju prvi pisal o tem Jurij Kobe iz Poljan, še zmeraj v Beli krajini, leta 1847 v Kmetijskih in rokodelskih Novicah (Štrekelj 1904-1907: 610-611).

Cela vas se večkrat zbere na sprevod mrtvega, ako je bil v življenji v časti. Ne najet, ampak radovoljno gre ženski spol za takim mrličem in narekuje za njim, to je: na glas jokaje vse njegove dobre dela prešteje. Tù se ne poje nobena pesmica, ampak kar ktera

\footnotetext{
${ }^{5}$ Janez V. Valvazor, Die Ehre des Herzogtuhums Krain II, 305: »Bey ihren Leychen scheinet dieses schreibwürdig, dass sie ein altes Weib dingen, welches den Todten beweinen muss. Dieselbe singt nur gleichsam, doch ganz kläglich und erzehlt. Alles, was er in seinem Leben Gutes oder Rühmliches gethan, imgleichen, was er künfftig noch für schöne Thaten hätte thun können. Sie fragt auch den Todten ungefähr also: 'Warum bist du gestorben? Was hast du vermeynet? Warum doch? Hast du doch ein gutes, schönes, freundliches, getreutes etc. Weib gehabt? Liber, so sag mir doch dann, warum bist du gestorben? Ach du hast übel gethan, dass du bist gestorben!' Und dergleichen närrische Fragen thut sie an solchen ausgestreckten Tacitum noch mehr, doch alle gleichsam Gesang-weise mit einem traurigen Thon. Je besser ein solchen kann lamentiren und wehklagen, je öffer wird sie dazu bestellt. Sonderlich ist dieses bei Weinitz, wie auch über der Culp und selbiger Gegend da umher eine gemeine Weise, welche sie mit christlichen Nationen in der Türkey, sonderlich aber mit den Griechen und Russen gemein haben: wiewol manche Umstände dabey anders lauffen und mit den Ländern sich verwechseln."

${ }^{6}$ Prevedla Marija Stanonik. Upam, da je vsaj smiselno načelno sprejemljivo.

${ }^{7}$ Čeprav ga, po Štrekljevi navedbi, omenja tudi pri čakavcih okrog Reke (Štrekelj 19041907: 611; Janez V. Valvazor, Die Ehre des Herzogtuhums Krain II, 624).
} 
vé od njega, to tako sostavlja in na take besede vdark deva, da se vezano izgovarja, včasi tudi ne. De bo vendar bravec zapopadek od tega imel, naznanim upitje zakonske žene za svojim možem:

»Prelepi moj mili mož! komu si me izročil?

Zlato moje dobro! zakaj si me zapustil?« (Štrekelj 1904-1907: 610-611).

Primerjava navedkov iz obeh stoletij kaže, da je stilem retoričnih vprašanj, ob katera se spotika J. V. Valvazor, ostal v Beli Krajini veljaven še čez dvesto let.

Karel Štrekelj je prepričan, da se je narekanje za mrtvimi ohranilo samo še v Beli Krajini (Štrekelj 1904-1907: 526), pri čemer mu je v oporo Janko Barlè, ki je leta 1890 našel tak primer v Drašičih:

Narekovale so navadno starejše žene, katere so za to dobile neko nagrado. Ko sem l. 1890 nabiral v Drašičih (župniji metliški) narodno blago, povedala mi je tedaj 73 let stara Ana Kozjan, kako so pred leti v Drašičih narekovali za materjo:

'Jojli mama, mila majčice, kam grete od mene na dalke pote, na dalke pote nespovratljive. Iz črne gori v ravno pole, saj čete tam najt' tri hladne zdence. Kada pridete k prvemu zdenci, ne pite mi vi une vodi, od une vodice glavica boli. Kada pridete k drugemu zdenci, ne pite mi vi une vodi, od une vodice srdašce boli. Kada pridete k tretjemu zdenci, ne pite mi vi une vodi, una vodica je nespovratljiva. Jojli mama, mila majčice, saj čete tam najt' tri kola ljudi, oni vas bodo iz dalek poznali. V prvem koli so mila majčica in dragi čačko. Oni vas vodo iz dalek poznali in vas bodo tam maj [= med] se zvali: 'Hod'te vi, hod'te $k$ nam kola igrat! Nute jim se lipo pričajte: 'Ne grem ja, ne grem k vam kola igrat, zakaj sem jako trudna i nevoljna. Duma sem pustila drobno dečico, oni so za me tužni i žalostni!' - Hitite maj njih kito bárovo [= borovo]. Dokle se bodo za njo jagmili, saj čete ta čas dalek dojti. V drugem koli so ti srednji ljudi [= prijatelji in znanci]. Oni vas bodo maj se zvali: Hod'te vi, hod'te $k$ nam kola igrat!' Pokle jim se lipo odrečte: 'Ne grem ja, ne grem $k$ vam kola igrat, zakaj sem jako tužna i žalostna!'

Tretje kolo je teh mladih ljudi, v njem čete najt dečico svojo. Saj vas bojo lipo prašali: 'Hod'te vi, hod'te k nam kola igrat!' nute jim se vi lipo zahvalite: 'Ne grem ja, ne grem $k$ vam kola igrat, zakaj sem jako tužna i žalostna!' - Kada zamažete to belo ruho, pošljite vi to belo ruho po drobni tici lastavičici, saj vam ga ne bomo oprali v hladni vodici, neg vam ga bomo sušili na hladnem veterci, neg' vam ga bomo sušli na srci svojem. Jojli mama, náredno (= lepo, spretno) íme, koga bom ja rada imela? Druge čerkice bodo imele majčice, ja vas pa ne bom nikir videla. Jojli mama, mila majčice, joj mama joj! (Štrekelj 1904-1907: 611-612)

Kadar so narekale, so večkrat pristavile »joj mama joj« in podobne pristavke in izraze žalosti. Tedaj bi se prvi stavek tako-le glasil:

Jojli mama, mila majčice, kam grete od mene, joj mama joj, na dalke pote nepovratljive, joj mama joj, oj na da dalke pote, joj mama joj! (Barlè 1899: 256).

Janko Barlè upravičeno piše o zelo starem narekanju z mnogo bajeslovnimi motivi in močnim pesniškim izrazom. Njegova želja, da bi se kdo poglobil vanj (Barlè 1899: 256), se do danes še ni uresničila.

Število tri in motiv treh studencev spominjata na pravljice, v katerih mora junak uspešno premagati ovire, da pride do cilja ali reši uganko. Toda tu ne gre za pravljico. Motiv vode spominja na mitično reko Stiks, čez katero Haron prevaža duše umrlih in bogovi pri njej izrekajo najsvetejše prisege (Verbinc 
1968: 677). Ljubkovanje je izraženo s številnimi manjšalnicami, ki so stalnica vseh nárečnih besedil v tem žanru.

Za primerjavo, kakšno je utegnilo biti tudi v Beli krajini narekanje za možem, Karel Strekelj objavlja primer iz Stupnika pri Zagrebu. Po nekaj korakih pogrebnega sprevoda sta se starejši ženi prijeli za roke in začeli peti pokojnemu. ${ }^{8}$

\subsection{Istra}

Leta 1853 je Jakob Volčič objavil nekaj člankov o narekanju v Istri. Poleg besedil je njegov opis šege najbolj celosten, saj ji sledi vse od umiranja do vrnitve domov po pokopu, in to glede na to, ali je pokojni/-a poročen/a ali samski/-a.

Sledi njegov poknjižen in delno prirejen opis: Ob bolniku plačejo* (*plakati - weinen), kar je drugo kakor jokati* (*wehklagen). Kakor hitro se duša loči od telesa, vse ženske v hiši, od najmanjše naprej, poljubujoč mrtvega na ves glas narekujejo; pomagat pridejo tudi sosede od najbližjega sorodstva in se ne dajo od njega ločiti, dokler jih druge ženske ne odvlečejo proč, da pokojnega preoblečejo in položijo na pare. Dokler je mrtvi v hiši, vzdigne enkrat ena ali druga svoje narekovanje. Ko ga »v trugo devajo« za pokop, »padejo vse z rokami in obrazi nanj, ter včasih glavo nekoliko vzdigovaje in z rokami ploskajoč narekujejo, katera to bolje zna.« Poročenega mrliča takoj doma pokrijejo »in $v$ trugo zabijejo«, neporočenega pa, »kjer se je še stara navada ohranila«, nosijo v odprti »trugi« in ga pokrijejo, preden ga dajo v jamo. Kjer v sprevodu z njim počivajo, se narekovavke brž zgrnejo okoli »truge«, ter padejo s sklenjenimi rokami in obrazi na nanjo in narekujejo, kakor tudi po vsej poti, tako tudi v cerkvi. Molčijo le »med merlicami (biljami $=$ viglia $=$ vigilia $)$ in med s. mašo«. Ko pa duhovnik zapoje: reši me gospod (libera), spet začnejo narekovati, kolikor močneje katera more, padajoč z obrazi in rokami na »trugo«, dokler je nosači ne odnesejo do groba. Ko nosila pri grobu položijo na tla, pri priči zbežijo, kakor da nikakor ne bi mogle gledati, kako telo njihovega ljubljenega $\mathrm{v}$ grob polagajo in s črno zemljo pokrivajo, ter domov gredé stalno narekujejo in plačejo, kar še doma včasih ponavljajo (Volčič 1853b: 247).

Volčiču sta besedila narekovali dve stari ženi, kakor sta mu jih povedali vsaka zase, češ: s pogrebov si jih ni mogoče zapomniti, ker poje vsaka po svoje. Narekajo za sinom, hčerjo, možem, očetom, materjo in sestro (Volčič 1853a: 180). Najbridkejše je za sinom:

Sine moj! Ran moja! sinko moj!

Rožice moja! diko moja! sine moj!

Kito moja! ranjena je majka, sine moj!

Rano moja! ranjena je majka tvoja, sine moj,

${ }^{8}$ S Bogom, s Bogo parec i pajdašec, / Gda bu sada kaj preskrbel / Dečici i mene? / Nismo mi tak dokončali, / Da se bumo mi rastali. / Mi smo lepo dokončali, / Da si bumo dečicu hranili. / Parec, parec i pajdašec, / Zakaj si meti prevaril, / Samu s decom sad ostavil? (Štrekelj 1904-1907: 612). 
Ja sam mislila, da češ ti mane, grančice moja«

Va mojoj starosti merzlom vodicom napajati, sine moj!

Lepi naš oženja brez nevestice, sinko moj!

Sine moj, serdačna grančice moja, sinko moj!

Ka se je mene od serdašca odkinula, sine moj!

Sinko moj! ranjena je majka tvoja, sine moj!

Guboka rano moja! serdačni sinko moj!

Nikdar nezagojena rano moja, sine moj,

Ki bi bil to meni rekal, rožice moja!

Da češ ti tako berzo oleteti, grančice moja,

Okrunjena grančice moja! sinko moj!

Ranjena je, majka tvoja! Rano moja sine moj!

Guboko nezagojena rano moja! sinko moj!

Nikdar nepozabljeni sine moj!

Sinko moj! ja sam mislila, rožice moja!

Da češ ti mene v starosti nastati, sine moj!

Da češ me k grobu sprovadjat, grančice moja!

Pa sprovadjam jaz tebe, serdačni sine moj!

Ja te sve zazivam, predragi sine moj!

Pa se nečeš name obazreti, rožice moja!

Sinko moj! rano moja! sine moj!

Vela moja nadajo! Serdačni sinko moj!

Ča puta si ti tvoju majku zazval, sine moj!

sada ti vela nuja serce oklopila, rožice moja!

Da nemoreš ti tvoje mile majke zazvat sinec moj!

Lepa okrunjena grančice moja, sinko moj!

Po malo mi tamo rožice deli, sine moj!

Aš le ti ih nestati, serdačna rožice moja!

Aš je tamo čuda rodbine i bratje, sinko moj!

Podeli mi ovih rožic, lepa grančice moja,

Ke su okolo tebe, serdačna kitice moja!

I sveh mi tamo pozdravi, sinko moj,

I mojga otca i milu majku, grančice moja,

I svih naših prijateli, serdačni sinko moj! Itd. (Volčič 1853a: 180).

Nagovori, ponavljanje celih vrstic ali besednih zvez, vsekakor pa epifora, $\mathrm{tj}$. ponavljanje svojilnega zaimka na koncu vrstice, manjšalnice in motiv rožice / grančice (veje) kot metafori za presekano rodbinsko kontinuiteto, so glavni stilemi prvega istrskega besedila.

V náreku za hčerjo obstajajo enaka formalna jezikovna sredstva: nagovor, ponavljanje, manjšalnice, celo motiv rožice in grančice se ponovi, na novo pa se pojavi motiv jelvice (jelke):

Hči moja! tanka jelvice moja, hči moja!

Lepa i serdačna rožice moja! ran moja!

Ranjena je majka tvoja, hčerko moja!

Ka sam se jako va te ufala, rožice moja!

Da češ mi bit' pomoć u nemoć, hći moja!

Lepa naša nevestica brez oženje, hći moja!

Ku sam imala za zercalo, grančice moja!

Rano moja, nikdar nezagojena rano moja! 
Vela nadajo moja, ljubeznjiva hći moja!

Lepo te prosim, serdačna grančice moja!

Da ni tamo svih lepo pozdraviš, hči moja!

I svu našu rodbinu i prijatelje, hći moja!

Podeli mi teh svojih rožic hći moja!

Ma ih po malo deli, lepa rožice moja!

Aš je tamo čuda šlo naših prijatel, hći moja!

Pak su mi te k sebi pritegnuli, jelvice moja!

Hči moja! Serdačna ranice moja!

Nikdar nezagojena rano moja! hći moja!

Ranjena je majka tvoja, hči moja!

Lepa moja grančice, hći moja!

Ka se je meni od serca odčihnula, hći moja!

Ki bi bil meni to rekla, rožice moja!

Da češ timeni tako berzo oletet', hći moja!

Letuća ptičica moja, serdačna hći moja!

Serdačna i uboga rano moja, hći moja!

Nikdar nezagojena ranice moja, hći moja!

Ja sam se nadjala, tanka jelvice mojal

Da češ ti meni laginu delat', hćerko moja!

Ja sam se nadjala, plemenita rožice moja!

Da češ mi bit' vela pomoćnica, hći moja!

Da češ me premagat u veloj potrebe, hći moja!

I va nujnoj posteli* $\left.{ }^{*}=\right]$, serdačna grančice moja!

Hćerko moja! ranjena je majka tvoja, hći moja!

Ki bi bil meni to rekal, lepa rožice moja!

Da češ ja tebe do grobića sprovadjat', hći moja!

I tvoja merzla lica obuševat ${ }^{* *}$ [** = kuševati, poljubljati] hći moja!

Serdačna moja grančice hći moja, Itd. (Volčič 1853a: 184).

Narekanje za otrokom (sinom in hčerko) je bolj neposredno, lirično, medtem ko se v náreku za možem čuti spoštljiva zadržanost, ki jo povzroča dosledno vikanje in izmenjavanje vokativa s samostalnikom drug / druže in mož (mužu). Ponovijo se motivi iz rastlinskega sveta in se v skladu s težo izgube nadgradijo $\mathrm{z}$ motivom posekanega drevesa.

Ah druže moj! ljubeznjivi druže moj!

Ah druže! Nemila je vaša sirota, druže moj!

$Z$ ovemi malemi grančicami ograjena, druže moj!

Kemu ste ih vi naručili, druže moj!

A nemila je vaša sirota, mužu moj!

Ah kruta ja sirota, mužu moj! druže moj!

Ah kruta i ranjena mili druže moj!

$Z$ ovim malim siroticam ograjena, mužu moj!

Kemu ste ih vi naručili? Mane! druže moj!

A sam z njimi kruta i ranjena, druže moj!

Kako i drevo odsečeno, mili druže moj!

Ah nemila ja vaša sirota, mužu moj!

Ah kruta i ranjena ja vaša sirota, druže moj!

Ah sinki moji mili, umerši sinci moji! 
Pridite vi na prot, mili sinci moji!

Ovemu vašemu otcu, mile grančice moj!

Aš je on jako nujan i nemoćan, sinki moji!

A lepo ja vasi ljubeznjivo prosim, sinki moji!

Da mu vi pridete sprotu, sinki moji!

Aš ste vi tamo spoznali pute i staze, sinki moji!

Lepo mi ga k sebi pritegnete, mili sinki moji!

Nemila ja njegova sirota, druže moj!

Ah serdačni druže moj!

Ah dobri moj prijatelju, druže moj!

Ah serdačni moj prijatelju, druže moj!

Nemila ja vaša sirota, druže moj!

Druže moj! kamo ću se ja uteći, mužu moj!

V svojih velih potrebah; druže moj!

Ako ne tuju tujicu, krepki boru moj!

A tujica je nemilica, mili druže moj!

Sirotica jaz brez vas, dragi i mili druže moj!

Lepi moj pogovoru i razgovoru, druže moj!

Ljubeznjivi i prijaznivi druže moj!

Kako ću ja brez vas živeti, boru moj!

Teško i žuhko življenje brez vas, mužu moj!

Ah razsuta kuća i imenje, druže moj!

A brez dobrega gospodara svojega, druže moj!

Kaka ču ja živet brez vas druže moj!

Ah razsuta kuća vaša, druže moj! Itd. (Volčič 1853a: 188).

V Istri je to izrecno za ženske rezervirana šega. Moškemu, ki bi začel za kom »narekovati«, bi se posmehovali; ženski, ki za svojim bližnjim in sorodniki ne bi narekala, pa bi zelo zamerili (Volčič 1853b: 247). Poleg samih besedil, to je ravnine teksta, Jakob Volčič največ pove o ravnini teksture, $t \mathrm{j}$. načinu izvajanja narekanja:

Posebnih narekovavskih pesem nimajoč jih skladajo kakor jim jih ožalosteno serce tisti čas navdaja, po nekih vendar stalnih oblikah, ki jih pojejo z otožnim in žalostnim napevom, ko dvigajo glas in ga natezajo, kamor stavljajo imena žlahte in druge ljubeznjive in mile priloge rajnemu, ter jih skoz celo pesem na koncu verste med sabo menjajoč ponavljajo, na priliko:

Za sinom: Sine moj, sinko moj! grančice moja! hči moja!

Za hčerko: Hčerčice moja, rožice moja, lepa kitice moja! Tanka jelvice moja! rano moja!

Za očetom: Čaćo moj, dobri čaćko moj! velo dobro moje!

Za materjo: mila majko moja, mila i draga majčice moja!

Za bratom: Bratac moj, brajne moj!

Za sestro: Sestrice moja, mila sestro moja! dobra prijatelica moja!

Za možem: Druže moj! mužu moj! rano moja! / Serce moje! Veliko dobro moje, boru moj! (Volčič 1853b: 247).

Besedila nastajajo sproti, toda iz navedenih primerov se vidi, da tudi tu obstaja institucija »potujočih verzov«. Narekajoč - milo opevajo tugo in žalost, da so rajnega izgubile, kako težko in mučno bodo brez nje/njega živele, prosijo 
prej umrle iz njene/njegove rodbine, naj mu pridejo naproti, prosijo umrlega, da jih lepo pozdravi in jim pove, kako zelo žalujejo za njim (Volčič 1853b: 247).

Če je pokopališče blizu cerkve, kamor hodijo k maši, začnejo blizu groba spet narekati in stojé tako plakajoč nekaj časa. Po maši poškropijo grob z blagoslovljeno vodo (kar radi počno na svojih grobovih tudi drugi) in narekajo, dokler jih druge žene ne odpeljejo. Volčič pravi, da je prav táko ob grobu pevajoče narekanje najlepše poslušati. Mrliča spremljajoče ženske ne narekajo samo za zdaj umrlim, temveč tudi za drugimi, vsaka svoje, za katerimi jih srce bolj boli. Včasih se starim ubogim ženam kaj daruje, da gredó narekovat (Volčič 1853b: 247).

Volčič si ne more kaj, da ne bi poudaril svoje narodne pripadnosti: najbolj gane Slovana, ko jim kateri dragih umré, sliši narekati v njegovem jeziku gospé in gospodične iz bogatih hiš, kjer se kakih petdeset let sem ilirska beseda že redko sliši:

Kadar ranjeno serce vse drugo preoblada, lepo milo ter milo čisto ilirski narekovati začnejo in s tem kažejo, da jim bog je slovansko kri v serce vstvaril (Volčič 1853b: 247).

Glede na današnjo zamegljeno slovensko narodno zavest v Istri je omeniti, da so sredi 19. stoletja območje, od koder je poročal Jakob Volčič, in je danes hrvaško, imeli za slovensko. Obakrat je obravnavana snov uvrščena v rubriko: Šege narodske po Slovenskem (Volčič 1853a: 180, 184, 188); šege slovenske (Volčič 1853b: 247). Ali je to odločitev avtorja ali uredništva?

\subsection{Rezija}

Vilko Novak navaja narekanje tudi v Beneški Sloveniji, toda ni znano, na podlagi katerih virov, verjetno Simona Rutarja, ki ga omenja Boris Orel (Rutar 1899). V novejšem gradivu (Merku 1976) o narekanju ni sledu. ${ }^{9}$ Pač pa se je zelo nazorno sporočilo o obrednem žalovanju ohranilo iz Rezije:

Kadar vzdignejo merliča, da bi ga iz hiše nesli, začnejo na ves glas jokati in žalovati vsi njegovi sorodniki in znanci, da je joj, in to terpi celo pot noter do cerkve; v cerkvi se ta jok en malo utolaži med svetim opravilom začne pa zopet po tem in še z večim krikom, kadar merliča v jamo spuščajo. Ni je pogrebščine na Rezianskem, pri kteri bi se ne slišal tak glasen jok in stok, in sicer je to žalovanje mnogokrat prisiljeno, ker je taka navada. (Slovenski prijatel 1856: 90).

\footnotetext{
${ }^{9}$ Pač pa obstaja o tem posredni terenski vir. Na pogreb Cirila Bogataja iz Osojnice leta 1952 so prišli v Žiri (Dobračeva) sorodniki iz Beneške Slovenije in so na pogrebu zganjali velik kraval, tj. strašno naglas jokali in »vpili«. To je bil čas, ko je bila meja težko prestopna, zato so pogreb snemali, da bi bili pri ogledu posnetka lahko simbolično zraven tudi tisti, ki niso bili na pogrebu. O tem je pisala k vojakom nečaku Alfonzu Zajcu z Dobračeve teta Mica. Terenski vir, sept. 2009.
} 
Po opisu sodeč je ta tip narekanja precej podoben tistemu v Istri, saj poteka vse od slovesa od doma in so v njem udeleženi vsi navzoči domači. Drugih podatkov zaenkrat o njem ni.

\subsection{Prekmurje}

Sredi druge polovice 19. stoletja Madžar Bálint Bellosits (1867-1916) v več spisih poudarja, da »so naši Prekmurci sorodniki Slovencev v avstrijskih kronovinah in pravzaprav ustvarjajo polotok velikega slovenstva, segajoč na madžarsko ozemlje« (Novak 1977: 168). Med folklornimi pesmimi objavlja balado »Sinek Martinek« s stranskim motivom naricalke (Novak 1977: 170). Ali je to spodbudilo Antona Trstenjaka, da je leta 1884 v Slovanu objavil članek, v katerem piše tudi o naricanju. V nasprotju z Belotinci [Beltinci], kjer da je manj izrazito in nekako bolj »moderno $«,{ }^{10}$ za veliko pieteto do pokojnega hvali prebivalce »Senika blizu sv. Gotharda na reki Rabi, na skrajni severni meji slovenskega življa na zahodnem Ogrskem«, Samo na Seniku in v njegovi okolici da »se žene jočejo in pojo pri pogrebu« (Trstenjak 1884: 341). Tega srčnega jokanja si človek še predstavljati ne more (Trstenjak 1884: 341).

Sledi obredno besedilo, s katerim se ob grobu žena poslavlja za možem:

Dragi moj tiváriš, zdaj si me tü odstávo, ka bom ja zdaj čínila; nindik nikoga nejmam. Dragi moj golobec, lübleni moj tivariš, kedvešni moj tiváriš, slatki moj oča, ka bom ja činila; što de mi vejčice (otroke) ráno [hranil], na koga se naslono; lübleni moj oča, što de mojo gazdijo gospodarstvo) odprávo [opravljal], što de na me na zrankoma gore góno [= zjutraj zgodaj zbujal], da nindik nikoga nejmam ... Kak si zdaj začnemo, kak mo zdaj živéli? Što de nam krüj priprávlo, što de nam njive oráo, što de nam sejo, što de nam senožete kosio, što de lepe lačen óso; hodliške lače správlo; što de rano gor stanjüvo, držino gono; što de roso dol klačo; što de m drva správlo, spičlinje (smrekove iglice) domou vozo; što de naše svinje v rede jemo pa kipüvo; što de našo máro, krave česo pa krmo; što de mlajše (otroke) gor rano, nje gvánao; što de méne rano; što de makove reteše gjo; što de nam zrezanice správlo. Lübleni moj tivariš, ti si me v dovinstvi odstávo; kak grlica na vejčici sama sam ostanola ...

Što 'de nam kaj zapovédo, ka 'mo zdaj mi činili, ka smo velike sirote austale. Sama si ležem, sama si stanem; $v$ noči na postele si premišlavam o tebe, ka mi nikdar več nazaj $k$ mene ne prideš; na veke si me odstávo, ka te veče nigder nazaj ne fčakam. Što 'de nam porcije [davek] správlo, što 'de nam obütev spravlo; nejmamo soli, što nam je küpi, nejmamo zábela, što nam perpravi; nejmamo krüja; deca nam menov joče, velikou žalost si na tem obŕrno, ka smo ednok veliki siromacje ostali. Dragi moj ftič, lübleni moj golob, zlati moj angeo, na veke si nas tünjao [zapustil], ka smo veliki siromacje ostali. Sákši siromák má svojega stáriša, mi ga pa nejmamo; sakši [vsak] na nas krči; sakši na nas kaže, ka smo velki siromacje ostali od tistij máo, ka si ti nas tünjao. Dragi moji, dobri lagovi, si nafküp lepo zahvalim, ka ste mojega slatkoga tivariša sprevodili; sejm vam zahvalim, ki koli ste tü; mali, veliki, stari, mladi, dobri moji pojte z menov na

10 »a na jugu že ne poznajo te navade. Na dan pogreba pride učitelj, poje in v pesmi jemlje $v$ imenu mrliča slovo od vseh sorodnikov, prijateljev in znancev ter imenuje vsakega po imenu« (Trstenjak 1884: 341). 
slednjo njegovo trobíno, ka nikdar več nemoga vidli, pa nemo gučali ž njim; eto je vse našo slednjo na etom svejte zdaj fküp bilo ž njim. Dragi tivariš, jezerokrat z Bogom, več te nemo vidla! Bog daj, ka 'ma se pred božim licom vidla! Sunce, mejsec i zvezde tebi večno svetijo! Lübleni tivariš, jezerokrat z Bogom! Bog daj, ka 'mo se na dr'ugom svejte vsi fküp veselili! Amen. (Trstenjak 1884: 341)

Objokovanje gospodarja, ki je skrbel za živino, gre tako daleč, da je med jokom celo slišati: »što de naše svinje v rede jemo pa kipüvo, što de našo máro, krave čèso pa kŕmo." (Ložar-Podlogar 1989: 163).

Zapis tega narekanja je prvovrsten dokument za študij, za kaj vse je moral gospodar skrbeti na posestvu in v družini (Mukič, Kozar 1982: 106). Kljub temu ni brez poetičnih sredstev, saj moža primerja s pticami (ptič, golob, orel). Morda so perutnice tisti vezni člen, ki jih povezuje $z$ onstranskim(i bitji), saj imajo angeli v folklorni ikonografiji tudi perutnice. Ponavljanje je manj razkošno, saj je le »lübleni tivariš« stalna besedna zveza, ki izstopa v sicer zelo stvarnem besedilu.

Vdova z otroki še pristavi:

Deca moja draga, spomente se s pokojnega očí ino vörno za njega Bogá mólte. ${ }^{11}$

Na gomili se proti koncu svojega narekanja vdova lepo zahvali vsem, da so spremili pokojnega $\mathrm{k}$ večnemu počitku in povabi vse na zadnjo 'trobüno' [?], tj. pojedino, ki jo priredi še isti dan in jedo vse, kar imajo. Dostikrat se na njej pogovarjajo, kako se je ta ali ona bridko jokala po svojem možu.

Hčere za umrlo materjo utegnejo pristaviti:

Što 'de nam len [= lan] spravlo, što 'de nam gvont pa sükne spravlo, vankiše? Póstele, mi odslovlene sirote brezi matere; na nas nišče ne 'de gledo. Što nas k možej da, da smo mater zgübile. Bog nas dünok pod svojo obrambo vzeme. Dragi bratre, Jože, Miško, Zdaj smo mater zgübili, nejmamo več vüpanja, kom se naslovimo - na Bogá. (Trstenjak 1884: 342).

Kadar komu umre žena, se možje samo jočejo, toda ne narekajo (Trstenjak 1884: 342).

Že zaradi primerjalnega študija je vsekakor prav, da Trstenjak ne spregleduje sosedov: pri Madžarih da se ženske jočejo pri pogrebu za denar; človek si táko lahko najame. Več ji plača, bolj se joče. Omenjeno ravnanje že nakazuje propadanje narekanja. Prav tako njena šaljiva obravnava:

Rado se primeri, da kdo od znancev potolaži vdovo ter jo vpraša, zakaj se je tako močno jokala, »saj«, pravi on, »vzamem te lahko jaz za ženo, če si z menoj zadovoljna."»Oh, ko bi to prej znala, " odgovori mlada vdova, »ko bi vedela, da ti misliš na me, pa se ne bi tako močno jokala. "Tako je človeško življenje; človek se lahko razjoče, še lažje razveseli. (Trstenjak 1884: 342).

${ }^{11}$ Kozar-Mukič (1988: 135) ima namesto »oči« »očé ...« 


\subsection{Poljanska dolina}

»Tu in tam slišimo še danes, da preide jokajoča žena ob pogrebu v glasno poslavljanje od rajnkega« (Novak 1960: 190), končuje (moj) profesor etnologije, Vilko Novak, svoj zapis o narekanju. Šele čez leta sem se ovedela, da sem bila takim žalnim klicem priča v otroštvu na pogrebih tudi v Poljanski dolini na Gorenjskem. Presunljiv jok s prav tako presunljivimi klici se je razlegel najprej na domu, ko je pokrov krste zagrnil pokojnikovo obličje in so ga zabijali z žeblji, in predvsem tedaj, ko so pogrebci spuščali »trugo«/ krsto v jamo, ter potem, ko je duhovnik zapustil prizorišče.

Predvsem nanje se je nanašalo vprašanje, ko so navzoče na pogrebih tisti, ki niso bili zraven, spraševali: »Ali so kaj jokali?« Še slišim presunljive klice, toda kaj, tega se žal ne spominjam več. Nisem vedela, da bo to kdaj predmet moje razprave. Ni mogoče reči, ali to še sodi k narekanju. Ali pač?

To in nekatera druga znamenja kažejo, da je do pred nekaj desetletji neke vrste narekanje obstajalo tudi v osrednji Sloveniji.

M. M. je takoj po smrti svojega moža, ko še niti preoblečen ni bil, jokala okrog hiše: »Zdaj bom pa sama. Zdaj pa ne boš več jamral. Zdaj pa ne boš več jamral.« V bolezni mu je bilo zelo hudo.

Obnašanje I. P., ene od žena v Žirovskem Vrhu nad Gorenjo vasjo, na pogrebih so njeni bližnji odklanjali, ker da preveč »udeluje«, »zeva«, »vpije«. Posmehovali so se ji, da pretirava, »se (preveč) žene«. Govorili so, da je bila zato »naštimana«, naprošena.

Za ženo, ki je v isti soseski v Žirovskem Vrhu na pogrebih »svetila«, tj. skrbela za sveče, se zahvaljevala kropilcem, tj. tistim, ki so se prišli od rajnega poslovit, prav tako pravijo, da se je »tudi gnala, na glas jokala in kaj pokomentirala za takim, ki »so ga radi dali«: »Ker ni bilo drugega, sem pa jaz povekala.« Včasih je bila za to tudi naprošena.

V Žireh sta bila sestra in brat Lipče in Franče, ki sta se preživljala iz rok v usta. Včasih sama od sebe, včasih pa naprošena, sta jokala za kom, za katerega drugim ni bilo mar. V zahvalo so ju povabili na sedmino ali pa sta se kar sama.

\section{Sklep}

Skrajni čas je za temeljito poetološko analizo narékov, saj navedeni redki, a dragoceni primeri izpričujejo neverjetno pesniško intenzivnost, ki jo spodbujata izjemno močno doživljanje in čustvovanje.

Iz zbranega gradiva se vidi, da

a) obredna besedila ohranjajo pradavne mitološke poteze (Bela krajina),

b) podatke o njihovem izvajanju (Istra),

c) znamenja propadanja njihove prvotne vloge (Rezija),

č) zato so izjemen dokument nekdanjega življenjskega stila (Prekmurje in Porabje). 
Kakor ugotavljajo dialektologi za jezikovne pojave, da se njihove arhaične oblike ohranjajo na robovih jezikovnih (narečnih) območij, se da podobna zakonitost potrditi za folklorna dejstva. Proces spreminjanja je od središčna proti obrobjem vse manj dinamičen, dokler skoraj ne izzveni, kar je povezano z zakonitostjo, da središča praviloma spodbujajo spremembe, robovi pa imajo nalogo ohranjati mejo s sosednjim, kulturno-jezikovnim, folklornim območjem.

Boris Orel ni dvomil, da je narekanje živelo tudi na Dolenjskem. Še leta 1940 je vaščanka iz Žigmaric pri Sodražici narekovala za svojim bratom na pogrebu v Ljubljani:

Prelepi moj brat, komu si ti mene zapustil! Sonce ne bo nikoli več tako lepo sijalo, kadar tebe več ne bo med nami ... (Orel 1944: 310-311).

Nov življenjski stil in miselni vzorci so prekrili prvotni pomen in smisel narekanja. Duhovno izpraznjen je še ohranjal pomen socialnega korektiva (narekale so uboge, revne žene tudi za plačilo).

Pozneje so narekanje nadomestili pogrebni govori. Ali so osmrtnice z verzi sodobna zamenjava za náreke?

Ali je beseda ica, -icati se, ki v Žireh pomeni jeza, jeziti se, ihta, biti ihtav kaj v sorodu z glagolom nar-icati?

\section{LITERATURA}

Janko BARLÈ,1899, Narodno blago. Narekovanje za umrlo materjo. Dom in svet 12: 256 .

Marija KLOBČAR, 2002, Štajerska slovesa - odsev družbene razslojenosti ali enakosti med ljudmi. Traditiones 31/2, 7-22.

Marija KOZAR - MUKIČ, 1988: Felsöszölnök - Gornji Senik. Szombathely-Ljubljana: Muzej Savaria, Znanstven inštitut Filozofske fakultete.

Zmaga KUMER, 1965: Potujoči verzi. Narodno stvaralaštvo - Folklor 4. Ur. Dušan Nedeljković. Beograd: Savez udruženja folklorista Jugoslavije.

--, 1968: Štajerska slovesa in njih mesto v evropski ljudski poeziji, Svet med Muro in Dravo. Viktor Vrbnjak. Maribor: Obzorja. 111-118.

Helena LOŽAR - PODLOGAR, 1989: Anton Trstenjak o ljudskem življenju v Prekmurju. Traditiones 18. Ur. Tone Cevc, Ljubljana, Inštitut za slovensko narodopisje Znanstvenoraziskovalnega centra SAZU. 147-166.

Pavle MERKU, 1976: Ljudsko izročilo Slovencev v Italiji / Le tradizioni popolari degli Sloveni in Italia. Trst: Založništvo tržaškega tiska.

Franček MUKIČ, Marija KOZAR, 1982: Slovensko Porabje. Celje: Mohorjeva družba.

Vilko NOVAK, 1960: Slovenska ljudska kultura. Ljubljana: Državna založba Slovenije. 
- -, 1977: Madžarski spisi o ljudskem življenju v Prekmurju. Traditiones 4, Ljubljana: Inštitut za slovensko narodopisje, SAZU. 155-174.

Boris OREL, 1944: Slovenski ljudski običaji, Narodopisje Slovencev 1. Klas: 263-349.

Simon RUTAR, 1899: Beneška Slovenija, Ljubljana: Matica Slovenska.

Marija STANONIK, 1995: Iz kaosa kozmos / Kontekstualnost in žanrski sistem slovenskega odporniškega pesništva 1941-1945, Ljubljana: Društvo za preučevanje zgodovine, literature in antropologije. 218-226.

Karel ŠTREKELJ, 1904-1907: Slovenske narodne pesmi III. Ljubljana: Slovenska matica. 610-611.

Anton TRSTENJAK, 1884: Navade v Prekmurcih, Slovan, političen in leposloven list I, Ljubljana. 341.

Janez V. VALVASOR, 1689: Die Ehre des Herzogtuhums Krain II.

France VERBINC, 1968, Slovar tujk, Ljubljana: Cankarjeva založba.

Jakob VOLČIČ, 1853a: Narekovanje v Liburnii (Istri) / Šege narodske po Slovenskem. Novice / kmetijskih, obertnijskih in narodskih reči. Ur. Janez Bleiweiss. tečaj 11, list 46, Ljubljana: 180, 184, 188.

- -, 1853b: Za merliči narekovanje v Istri / Šege slovenske, Novice / kmetijskih, obertnijskih in narodskih reči. Ur. Janez Bleiweiss. tečaj 11, list 46, Ljubljana: 247.

- -, 1856: Reziani! Slovenski prijatel. Ur. Andrej Einspieler. Celovec: 90.

\section{LAMENT - A LOST SLOVENIAN FOLKLORE GENRE}

Laments and lamentation started to dwindle in the mid $19^{\text {th }}$ century. Ritual lamentation of the deceased is a residue of Indo-European funeral rites. Its aim was to make as much noise as possible to chase away the evil forces who wanted to take possession of the deceased's soul. In the course of time this meaning of the custom faded and it moved to the field of the emotions accompanying dead. It started to lose its original function because there often was no genuine correspondence between the emotional attitude to the deceased and the intensity of the lamentation at the funeral. According to the first pattern, the higher the danger was of evil forces taking possession of the deceased, the stronger the lamentations had to be; this means that during his lifetime the deceased had been a very difficult person and that he was not liked very much. According to the second pattern, only loved persons were lamented.

The custom used to be common in Slovenia in the past. It was preserved longest in the border areas of the Slovene ethnic territory: Resia, Venetian Slovenia, Trenta, Istria, Bela krajina, and Prekmurje. A feature specific of Slovene Porabje was that a husband, too, lamented his deceased wife. To date no data have been found that would indicate a custom of lamenting in Carinthia. There are some indications that some kind of lamentation existed in central Slovenia until a couple of decades ago. 
The presented texts were published in newspapers in the mid $19^{\text {th }}$ century. They are here published together and in chronological order for the first time, making it possible to compare their contents and style.

It is high time for a profound poetological analysis of lamentations because the cited, rare but precious, examples reveal an incredible poetic intensity driven by very powerful experiences and emotions
a) The preserved ritual texts with ancient mythological features (Bela krajina)
b) with data on their performance (Istria)
c) and with indications of the deterioration of their original function (Resia)
d) are outstanding documents of a past lifestyle (Prekmurje - Porabje). 